\title{
A Clinical Study on the Influence of Sinusitis in Chronic Suppurative Otitis Media
}

Sellappampatty Veerappapillai Dhanasekaran, ${ }^{1}$ Jiji Sanjeevan Nair, ${ }^{1}$ Komathi Raja, ${ }^{1}$ Govind Krishnan Gopalakrishnapillai, ${ }^{1}$ Abhilash Kuniyath Chandran, ${ }^{1}$ Shankar Radhakrishnan ${ }^{2}$

Introduction

\section{ABSTRACT}

Diseases of the nose and paranasal sinuses are known to influence the middle ear conditions. In the evaluation of the patients with chronic otitis media, radiological, endoscopic, and other auxiliary diagnostic tools may have their roles in the objective assessment of the patients, and to rule out lesions of the nasal cavity and the nasopharynx as potential aetiological factors.

\section{Materials and Methods}

This cross sectional observational study was conducted for a period of two years to establish the role of sinusitis as focus of sepsis in patients with tubotympanic type of CSOM. All patients in the age group of 20-40 years with more than 2 months of ear discharge and with a hearing loss of $25-40 \mathrm{db}$ and diagnosed as tubotympanic type of CSOM were included in our study. Patients who had features of mastoiditis on X-ray and also with persistent ear discharge even after treatment with oral and topical antibiotics were subjected $(n=70)$ to diagnostic nasal endoscopy and computed tomography of paranasal sinuses.

$\underline{\text { Result }}$

Among the 100 patients of CSOM, 70\% had features suggestive of sinusitis. Deviated nasal septum (40\%) was the most common pathology among the study population. Majority (54\%) of them had mucopurulent type of ear discharge. The CT findings of the paranasal sinuses revealed that $48.5 \%$ of the study population had grade I type of involvement of the PNS. $54.2 \%$ of the patients had a large central perforation and the middle ear mucosa was found to be edematous for $65.7 \%$ of the patients.

Discussion

Coexistence of deviated nasal septum and chronic rhinosinusitis with discharging CSOM is at par with several other studies conducted in other parts of the world.

Conclusion

Deviated nasal septum, enlarged middle turbinate, medialised uncinate associated with sinusitis are the predisposing factors in the development of CSOM. So assessment for sinusitis in the treatment of CSOM should become a routine practice.

$\underline{\text { Keywords }}$

Otitis Media, Suppurative; Otitis Media with Effusion; Paranasal Sinuses; Maxillary Sinusitis

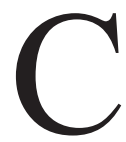
hronic Suppurative Otitis Media (CSOM) of tubotympanic type is a persistent inflammation that causes irreversible changes of the mucosa in the middle ear and mastoid cavity. It is characterized by a persistent discharge from the middle ear through a tympanic membrane perforation. It is an important cause of preventable hearing loss, particularly in the developing world (WHO, 2004). ${ }^{1}$ Its pathophysiology begins with irritation and subsequent inflammation of the middle ear mucosa. The most important pathological factors in CSOM are dysfunction of the Eustachian tube and bacterial infection. ${ }^{2}$ Obstruction of ET in turn leads to Otitis media (OM). Diseases of the nose and Paranasal sinuses (PNS) thus influence the middle ear condition.

Although most of the literature refers to sinusitis and upper respiratory tract as causative factor of otitis media, only few articles refer to actual nasal pathologies

1 - Department of ENT, Vinayaka Missions Kirupananda Variyar Medical College, Salem

2 - Department of Community Medicine, Vinayaka Missions Kirupananda Variyar Medical College, Salem

Corresponding author:

Dr Shankar Radhakrishnan

email: shnkr_radhakrishnan@yahoo.com 
involving anatomical factors that can lead to it. Those patients who have otitis media secondary to nasal and /or PNS pathology need to have both problems addressed. ${ }^{3}$

Sinonasal pathology frequently leads to ear disease. Improvement of otitis media pathology following septoplasty was noted by Grady (1983). ${ }^{4}$ Von Cauwenberge and Derycke $(1983)^{5}$ and Kim et al. $(1993)^{6}$ also showed evidence of association of sinonasal pathologies in cases of otitis media. Bozkuset et al $(2013)^{7}$ demonstrated that the role of sinonasal abnormalities and allergic rhinitis in the pathogenesis of chronic otitis media is prevalent. They concluded that although medical history and physical examination are considered mandatory procedures during the initial evaluation of the patients with chronic otitis media, radiological, endoscopic, and other auxiliary diagnostic tools should be used in the objective assessment of the patients, and lesions of the nasal cavity and the nasopharynx must always be taken into consideration in the differential diagnosis. Without correcting the sinusitis, the management of ear including surgery has frequently led to failures and poor prognosis. ${ }^{8}$ Therefore it is essential to establish the role of sinusitis as focal sepsis in chronic otitis media active mucosal disease.

\section{Materials and Methods}

A cross sectional observational study was undertaken in the ENT OPD for a period of two years from January 2013 to December 2014 to establish the role of sinusitis as focus of sepsis in patients with tubotympanic type of CSOM. All patients, in the age group of 20-40 years with more than 2 months of ear discharge and with a hearing loss of 25-40 dB and were diagnosed as tubotympanic type of CSOM, were included in our study. One hundred patients who met the above criteria were included in the study. X-ray of the mastoids was taken for all the patients. Patients with evidence of chronic sinusitis were treated with antibiotics and antihistamines and decongestants were given on and off for a period of 6 weeks.

Patients who had evidence of mastoiditis on X-ray and also with persistent ear discharge even after treatment with oral and topical antibiotics were subjected $(n=70)$ to diagnostic nasal endoscopy and computed tomography of paranasal sinuses.

\section{Results}

Table I shows the age and sex wise distribution of the study population. The majority of the study population were males and they were in the age group between 2030 years. Almost $90 \%$ of the study populations were from rural areas belonging to lower socio-economic status.

The findings of the nasal endoscopy were shown in

Table I : Distribution of Study Population as per Age and Sex

\begin{tabular}{|c|c|c|c|}
\hline $\begin{array}{c}\text { AGE } \\
\text { GROUP } \\
\text { (YRS) }\end{array}$ & MALE & FEMALE & TOTAL \\
\hline $20-25$ & 12 & 12 & 24 \\
\hline $26-30$ & 18 & 10 & 28 \\
\hline $31-35$ & 8 & 4 & 12 \\
\hline $36-40$ & 4 & 2 & 6 \\
\hline TOTAL & $\mathbf{4 2}$ & $\mathbf{2 8}$ & $\mathbf{7 0}$ \\
\hline
\end{tabular}

Table II. Deviated nasal septum (DNS) was the most common pathology (40\%) among the study population followed by enlarged bulla. Medialised uncinate was seen in $17.1 \%$ of the study population and $10 \%$ of them had enlarged bulla with prominent agger.

The type of discharge in the middle meatus viewed through nasal endoscopy had shown that almost $54.2 \%$ of the discharge was mucopurulent type and the remaining was either purulent or mucoid in nature (Table III).

The grading of paranasal sinuses based on CT findings had shown that almost $48.5 \%$ of them had grade I, where the disease is limited to OMC (ostiomeatal complex), $22.8 \%$ had grade II (incomplete opacification of one/more sinuses) $14.2 \%$ had grade III (complete opacification of one or more major sinuses) and 7.1\% 
had grade IV findings i.e., total opacification of all sinuses (Table IV).

Table II : Nasal endoscopy findings among study population

\begin{tabular}{|c|c|c|}
\hline $\begin{array}{c}\text { NASAL } \\
\text { ENDOSCOPY } \\
\text { FINDINGS }\end{array}$ & FREQUENCY & PERCENTAGE \\
\hline $\begin{array}{c}\text { Deviated } \\
\text { nasal septum / } \\
\text { turbino septal } \\
\text { deformity }\end{array}$ & 28 & $40 \%$ \\
\hline $\begin{array}{c}\text { Medialised } \\
\text { uncinate }\end{array}$ & 12 & $17.1 \%$ \\
\hline $\begin{array}{c}\text { Enlarged } \\
\text { middle } \\
\text { turbinate }\end{array}$ & 10 & $14.2 \%$ \\
\hline $\begin{array}{c}\text { Enlarged bulla } \\
\text { with prominent } \\
\text { agger }\end{array}$ & 7 & $10 \%$ \\
\hline TOTAL & $\mathbf{7 0}$ & $\mathbf{1 0 0} \%$ \\
\hline
\end{tabular}

Table III : Type of discharge seen in middle meatus during nasal endoscopy

\begin{tabular}{|c|c|c|}
\hline $\begin{array}{c}\text { NATURE OF } \\
\text { DISCHARGE }\end{array}$ & FREQUENCY & PERCENTAGE \\
\hline Mucopurulent & 38 & $54.2 \%$ \\
\hline Purulent & 18 & $25.7 \%$ \\
\hline Mucoid & 14 & $20 \%$ \\
\hline TOTAL & $\mathbf{7 0}$ & $\mathbf{1 0 0} \%$ \\
\hline
\end{tabular}

The anatomical variations of paranasal sinuses based on CT findings had shown that $40 \%$ of them had deviated nasal septum, $20 \%$ of them had medialised uncinate with maxillary mucosal thickening and $11.4 \%$ of them had prominent agger (Table V).

The otoendoscopy findings among the study population had shown that $54.2 \%$ of them had a large
Table IV : Grading according to findings of CT Scan of PNS

\begin{tabular}{|c|c|c|}
\hline $\begin{array}{c}\text { CT SCAN PNS } \\
\text { FINDING }\end{array}$ & FREQUENCY & PERCENTAGE \\
\hline Grade 0 & 5 & $7.1 \%$ \\
\hline Grade I & 34 & $48.5 \%$ \\
\hline Grade II & 16 & $22.8 \%$ \\
\hline Grade III & 10 & $14.2 \%$ \\
\hline Grade IV & 5 & $7.1 \%$ \\
\hline TOTAL & $\mathbf{7 0}$ & $\mathbf{1 0 0} \%$ \\
\hline
\end{tabular}

Table V : Anatomical variations as per CT Scan of PNS

\begin{tabular}{|c|c|c|}
\hline $\begin{array}{c}\text { ANATOMIC } \\
\text { VARIANTS }\end{array}$ & FREQUENCY & PERCENTAGE \\
\hline $\begin{array}{c}\text { Deviated Nasal } \\
\text { septum }\end{array}$ & 28 & $40 \%$ \\
\hline $\begin{array}{c}\text { Medialised } \\
\text { uncinate with } \\
\text { maxillary } \\
\text { mucosal } \\
\text { thickening }\end{array}$ & 14 & $20 \%$ \\
\hline $\begin{array}{c}\text { Enlarged bulla } \\
\text { narrowing } \\
\text { OMC }\end{array}$ & 7 & $10 \%$ \\
\hline $\begin{array}{c}\text { Concha } \\
\text { bullosa }\end{array}$ & 13 & $18.5 \%$ \\
\hline $\begin{array}{c}\text { Prominent } \\
\text { agger } / \\
\text { frontal cell } \\
\text { obstructing } \\
\text { frontal recess }\end{array}$ & 8 & $11.4 \%$ \\
\hline \begin{tabular}{c} 
TOTAL \\
\hline
\end{tabular} & $\mathbf{7 0}$ & $\mathbf{1 0 0} \%$ \\
\hline
\end{tabular}

central perforation of the tympanic membrane, $31.4 \%$ had a subtotal central perforation and the remaining $14.2 \%$ had only a small central perforation. The middle ear mucosa were edematous for $65.7 \%$ of the population 
and $34.2 \%$ of them had a polypoidal mucosa (Table VI).

Table VI : Otoendoscopy findings in study population

\begin{tabular}{|c|c|c|}
\hline $\begin{array}{c}\text { TYPE OF } \\
\text { PERFORATION }\end{array}$ & FREQUENCY & PERCENTAGE \\
\hline Large CP & 38 & \\
\hline Subtotal CP & 22 & $54.2 \%$ \\
\hline Small CP & 10 & $31.4 \%$ \\
\hline TOTAL & $\mathbf{7 0}$ & $14.2 \%$ \\
\hline
\end{tabular}

\section{Discussion}

The most important step in the diagnosis of chronic suppurative otitis media (CSOM) is to identify the underlying pathology, once it is identified, the treatment would be much simpler.

Keeping in view the importance of nasopharyngeal and sinonasal pathology of CSOM, the present study was carried out on 70 patients of CSOM presenting to our Outpatient Department of Otolaryngology. Age of patients ranged from 20 to 40 years with a mean age of $28.7 \pm 6.4$ years. Maximum number of patients (74.2\%) was aged between 21-30 years. CSOM is defined primarily as a disease of pediatric age group (Nelson, 1988). ${ }^{9}$ Other workers like Shrestha et al (2010), ${ }^{10}$ Karkiet al (2011) ${ }_{11}^{11}$ Poorey and Iyer $(2002)^{12}$ had found maximum prevalence of CSOM in the younger age group, which was almost at par with our study.

Several studies have proposed nasal septum deviation as a predisposing factor in patients with CSOM. Van Cauwenberge et al demonstrated that increase in nasal resistance leads to higher static middle ear, and closing pressures of the Eustachian tube pressure with resultant formation of mucosal edema and finally Eustachian tube dysfunction. ${ }^{13}$ Gutierrez-Marcos showed that obstructive septal deviation induces Eustachian tube dysfunction. ${ }^{14}$ Deron et al detected that opening pressure of the Eustachian tube recovers in the early, and late postoperative period surgical repair of the septal deviation. ${ }^{15}$ Using paranasal CT procedures, Gocmen et al reported septal deviations in 52\% patients with CSOM. ${ }^{16}$ It is almost at par with our study where we found $40 \%$ of patients with CSOM had deviated nasal septum.

Diagnostic nasal endoscopy findings of our study revealed DNS alone or in combination with other pathologies to be the most common findings. Similar observations were made by Yeolekar et al $(2011)^{17}$ in their study, sinonasal pathology was seen in $90 \%$ of the patients with CSOM.. Poorey and Iyer (2002) ${ }^{12}$ reported presence of pharyngeal and sinonasal pathology in $93 \%$ patients with CSOM.

In the literature, detection of sinusitis ranges between 43 and $78 \%$ in the patients with OME, supports the prevalent finding of inflammation in the upper respiratory tract as a culprit of OME. ${ }^{18}$ Fireman et al. emphasized that otitis media is a multifactorial disease which was effected by many etiologies including nasal, and paranasal sinus abnormalities. ${ }^{19}$ Eryilmaz et al reported the presence of chronic rhinosinusitis in patients with $(57.7 \%)$ and without $(25 \%)$ chronic otitis media with effusion (COME) with a significant difference between groups. ${ }^{20}$ Grote and Kuijpers detected maxillary sinusitis in $47 \%$ of 1252 pediatric cases with COME..$^{21}$ In the present study, maxillary sinusitis was present in $48.5 \%$ of cases.

Majority of investigators have revealed the important role of upper respiratory tract abnormalities as causative factors for Eustachian tube obstruction in the aetiopathogenesis of CSOM. ${ }^{11}$ Stammberger et al reported serious loss in Eustachian tube functions as a consequence of impaired function of nasal, and paranasal sinuses. ${ }^{22}$ Gocmen et al. detected chronic inflammation of the osteomeatal unit in $27 \%$ of 52 patients with adhesive otitis, and revealed that nasal, and paranasal sinus abnormalities were significantly different relative to the control group. ${ }^{16}$

Takashi et al demonstrated that inflammatory processes of nasal, and paranasal sinuses ensued in obstruction, inflammation, and resultant dysfunction of Eustachian tube. ${ }^{23}$ In our study maxillary sinusitis was found to be the most common type of sinusitis among 
the patients with CSOM. The same study showed that among the patients with CSOM, $62 \%$ of them had mucopurulent type of ear discharge and $60 \%$ had a large central perforation of the tympanic membrane and the results were almost similar to our study where $54 \%$ of them had central large perforation with mucopurulent discharge. Grote and Kuijpers ${ }^{21}$ in their study on the middle ear mucosa using otoendoscopy among the patients with CSOM revealed that $71 \%$ of them had edematous middle ear mucosa and $29 \%$ had polypoidal mucosa which was almost in par with our study.

\section{Conclusion}

This study had demonstrated that sinusitis is one of the most important predisposing factor in the development of CSOM. Deviated nasal septum, enlarged middle turbinate, medialised uncinate are the most common anatomical variants of nose and paranasal sinuses predisposing to sinusitis. So sinusitis should be considered as one of the most important risk factor in the development of CSOM and it has to be identified and treated promptly.

\section{References}

1. World Health Organization. Chronic Suppurative Otitis Media. Burden of Illness and Management Options. Geneva: World Health Organization, 2004. Available from: http://www.who. int/pbd/publications/Chronicsuppurativeotitis_media.pdf. Accessed April 27, 2016

2. Verhoeff M, van der Veen EL, Rovers MM, Sanders EA, Schilder AG. Chronic suppurative otitis media: a review. Int J Pediatr Otorhinolaryngol. 2006; 70: 1-12

3. De Souza C, Bhaya M. The role of nasal and sinus surgery in otitis media. Operative techniques in Otolaryngology. Head Neck Surg. 1996; 7:16-9

4. Grady D, Mathias P, Anderson R, Snider G, Sprinkle PM. Improvement of middle ear disease following septoplasty. Am J Otol. 1983; 4:327-31

5. van Cauwenberge P, Deryeke A. The relationship between nasal and middle ear pathology. Acta Otorhinolaryngol Belg.1983; 37: $830-41$

6. Kim CS, Jung HW, Yoo KY. Prevalence of otitis media and allied diseases in Korea- Results of a nation-wide survey 1991. J Korean Med Sci.1993; 8:34-40.

7. Bozkus F, Bozan N, Iynen I, Sakin YF, Kiris M. Analysis of sinonasal, pharyngeal and allergy-related risk factors for chronic suppurative otitis media. Acta Medica Mediterranea 2013, 29: 47-52

8. Bluestone CD. Epidemiology and pathogenesis of chronic suppurative otitis media: implications for prevention and treatment. Int J Pediatr Otorhinolaryngol.1998; 42: 207-36

9. Nelson JD. Chronic suppurative otitis media, Pediatr. Infect Dis. J. 1988; 7 (6): 446-8

10. Shrestha D, Thapa P, Bhandari YB. Types of pathology and ossicular status in atticoantral disease undergoing mastoidectomy at Bir Hospital. Journal of College of Medical Sciences-Nepal 2010; 6(4): 26-30

11. Karki R, Rai K. Pattern of Otorhinolaryngological Diseases at Rural Medical Camps in Far Western Region of Nepal. MJSBH July-December 2012; 11(2): 29-31

12. Poorey VK, Iyer A. Study of Bacterial Flora in CSOM and its Clinical Significance. Ind. J. Otolaryngol Head Neck Surg. 2002; 54(2): 91-5

13. van Cauwenberge PB, Vander Mijnsbrugge AM, Ingels KJ. The microbiology of acute and chronic sinusitis and otitis media:a review. Eur Arch Otorhinolaryngol. 1993; 250 Suppl 1: S3-6

14. Gutierrez-Marcos JA, Fandinoizun-Degui J, Garcia- Palmer R. Deviations of the nasal septum and their relation to tubal physiopathology. Rev Laryngol Otol Rhinol Bord. 1992; 113(5): 383-5

15. Deron P, Clement PA, Derde MP. Septal surgery and tubal fuction: Early and late results. Rhinology 1995; 33(1): 7-9

16. Gocmen H, Ceylan K. Burun ve paranasal sinus pathologies versus tympanic membrane pathologies. Otoscope 2004; 1 : 34-8

17. Yeolekar AM, Dasgupta K S. Otitis media: Does the onus lie on sinonasal pathology? Indian J Otol. 2011;17:8-11

18. Fujita A, Honjo I, Kurata K, Gan I, Takahashi H. Refractory otitis media with effusion from viewpoints of eustachian tube dysfunction and nasal sinusitis. Am J Otolaryngol. 1993; 14(3): $187-90$

19. Fireman P. Otitis media and nasal disease: A role for allergy. J Allergy Clin Immunol. 1988; 82(5): 917-26

20. Eryilmaz A, Akmansu H, Dursun E, Dagli M, Acar A, Turkay $\mathrm{M}$, et al. Is there a relationship between chronic rhinosinusitis and otitis media with effusion in pediatric patients? Turk Otolarengoloji Arşivi 2004; 42(3): 164-8

21. Grote JJ, Kuljpers W. Middle ear effusion and sinusitis. J Laryngol Otol. 1980; 94: 177-83

22. Stammberger H. An endoscopic study of tubal function and the diseased ethmoid sinus. Arch Otol Rhinol Laryngol. 1986; 243(4):254-9

23. Takahashi H, Miura M, Honjo I, Fujita A. Cause of eustachian tube constriction during swallowing in patients with otitis media with effusion. Ann Otol Rhinol Laryngol. 1996; 105(9): $724-8$ 